\title{
Changing Narratives of Intimate Partner Violence
}

\author{
A Longitudinal Photo-Ethnography
}

\author{
Heith Copes, Lindsay Leban, and Jared Ragland
}

ABSTRACT: We explore how women's narratives of abuse change, including narratives of self as well as narratives of their abusers. We draw on experiences from a photoethnography of people living in rural Alabama who use methamphetamine. The use of photographs taken throughout the project aid in both the representation of the women as well as in data collection (through photo-elicitation interviews). While we draw on the overall experiences from the project, we focus specifically on one key participantMisty-to illustrate the ways that she made sense of and excused intimate partner violence, and how her narrative eventually changes. Our findings illuminate how the narratives people construct of themselves are intertwined with those they construct with others, and how such narratives change together.

KEYWORDS: intimate partner violence, narrative criminology, photo-ethnography, photo elicitation

Narrative research focuses on the ways people tell stories to explain experiences, with attention to how they draw from common understandings, values, and customs to construct these stories (Holstein and Gubrium 2000). Exploring narratives provides important insights into social life, broader culture, and personal identity. The focus of narrative analysis is not simply on using narratives to make factual claims about people's behaviors or perceptions, but rather to understand how and why people construct stories and how these stories constrain action. Stories tell us about how people make sense of their experiences and how they shape future decisions. While disciplines such as anthropology have long used narratives and storytelling to understand culture and experience, within the field of criminology there is a growing use of narratives to understand past criminal behavior and to predict future behavior (Presser and Sandberg 2015). Narrative frameworks have shed light on how people use stories to make sense of their criminal behavior and victimization, including illicit drug use (McIntosh and McKeganey 2000), street violence (Hochstetler et al. 2017), and decisions to stay in (or leave) abusive relationships (Lim et al. 2015).

All people have multiple narratives of self and adapt or flex their narratives over time and between settings (Hammersvik 2018). People also shift their narratives depending on the context within which they tell them. The stories people tell in the midst of an experience differ from the way they tell stories after it. New events, changes within the relationship or within individuals, and changes in circumstances can lead people to shift their narratives and redefine themselves and others. Furthermore, the process of narrative change is typically accompanied by the reconstruction of a new identity, often viewed as the transition from an "old self" to a reconstructed "new self," which has been used to explain desistance from crime (Maruna 2001). 
Narrative research on victimology focuses on how people make sense of their victimization and how stories shape responses to victimization (Pemberton et al. 2019; Walklate et al. 2019). This work suggests that looking at narrative changes is important for understanding the lives of people who are victimized by crime. Longitudinal ethnographies are well suited to study narrative change because they allow for the ability to see changes over time. Accordingly, to understand how narratives relating to intimate partner violence change, we rely on data collected from an 18-month photo-ethnography of people who use methamphetamine (meth) in rural Alabama. Our analysis focuses on one key participant (Misty) to understand how people use narratives of themselves and of others to make sense of intimate partner violence and to illustrate how narratives change over time. The results show the importance of looking at intertwining narratives over time when understanding how people make sense of themselves and their lives. Our findings highlight the value of using longitudinal ethnographies in understanding narrative identities, as this approach enables researchers to chart narrative change better than purely retrospective accounts and provides insight into how life and situational changes influence narratives over time.

\section{Narrative Criminology and Intimate Partner Violence}

With roots in phenomenology, symbolic interaction, and interpretative psychology, narrative criminology views crime "as a function of the stories that actors and bystanders tell about themselves" (Presser 2012: 5). This perspective assumes that people use stories as a way to make sense of their actions, expose their expectations, and provide templates for future behavior (Presser and Sandberg 2015). Narratives are both derived from and reflective of social and cultural context. In telling stories, people draw on available cultural and social resources to construct narratives of themselves and of others. For instance, for many women involved in crime, narratives of self are heavily constrained by understandings of womanhood and femininity specific to their social position and class (Fleetwood 2014; Miller et al. 2015). Thus, narratives reflect the position of the person telling the story, with each person being limited to a pool of available narratives based on their social positions and experiences (Scott and Lyman 1968). Exploring narratives can provide insights into how social positions shape expectations, rationalizations, and sense-making.

Furthermore, stories can guide future behavior (Presser and Sandberg 2015). The narratives people construct also affect the way they respond to victimization; for example, by influencing self-protective measures or decisions to interact with the justice system. For those who are victims of crime, narratives are one way to construct identities as survivors, martyrs, or victims. These narratives help make sense of how the victimization occurred, understand the role of victims and perpetrators in the event, and shape sense of self.

In telling stories of themselves and of others, people draw from a variety of narratives, which can exist at multiple levels (e.g., cultural, organizational, or personal). Cultural narratives draw on broad, depersonalized assumptions of others and serve as ways of classifying abstract types of people (Loseke 2007). They are used to classify people into broad categories (e.g., abuse survivors, drug users, or good mothers). Oftentimes, these involve generalizations about people with little agency. Cultural narratives surrounding women victims of intimate partner violence often paint them as powerless, passive, and weak women who lack personal agency (Dunn 2005). Narratives are also embedded in geographical context. For instance, traditional ideologies of gender are prevalent in in rural areas of the Southern United States, which women are idealized as feminine caretakers and men as dominant breadwinners (Struthers 2014; Tigges and Choo 
2012). Such cultural narratives serve as mental shortcuts by which people evaluate others and make sense of themselves (Loseke 2007). People adapt these depersonalized cultural narratives to fit their own personal experiences, perspectives, and formulas for action, thereby forming a coherent personal narrative (Loseke 2007).

Personal narratives, then, represent a person's attempt to make sense of concrete events and experiences within the cultural narratives and discourses available to them, while maintaining characteristics and experiences unique to the individual (Sandberg 2013). Incorporating these cultural narratives of masculinity and femininity into personal narratives is one way people perform gender. For example, women experiencing intimate partner violence often draw on themes of women as caretakers to make sense of why they stay (Lim et al. 2015). That is, they draw on their role as nurturers taking care of sick partners or emphasize their role as mothers who need to keep their family intact to stress why they need to stay with their abusers (Ferraro and Johnson 1983). Often, women in such relationships take patriarchal, controlling, ideas of gender for granted. Implicit in their own narratives are assumptions that men control households, which includes forms of violence.

Most research on narrative identities focuses on how people construct personal identities. However, narratives are also used to make sense of other people's identities. Typically, when narrative scholars point to identities of others it is about stigmatized others (i.e., those we try to distance ourselves from). Thus, these narratives are often simple and present one-dimensional representations of the other and act as an out-group (Loseke 2007). However, narratives of others can also be personalized and complex, particularly of those with whom we are close. Narratives of others are also shaped by those same cultural and social factors from which our personal narratives are constructed.

Importantly for interpersonal violence, the way people make sense of their victimization can change. New events, changes within the relationship or within individuals, and changes in circumstances can lead people to redefine their abuse and abusers (Ferraro and Johnson 1983). Such changes can lead to changes in narratives, including the way people talk about themselves, their partners, and their circumstances. In turn, narrative changes can serve as turning points after which a person chooses to leave an abusive relationship. Furthermore, this process is often accompanied by the construction of a new identity. Given that abused women can experience feelings of guilt and shame surrounding their circumstances (Ferraro and Johnson 1983), new identities are typically constructed to accentuate their removal of the victim identity, emphasizing being an independent and empowered person (Meyer 2016). Through narratives, those who experience intimate partner violence can redefine themselves from "victims" to "survivors" (Brosi and Rolling 2010).

Due to the overlap in how we construct narratives of ourselves and close others, we argue that changes in personal narratives of themselves (as victims or survivors) and of the narratives they construct of their partners need to be looked at together to understand how people make sense of abuse and their decisions to stay or leave abusive relationships (Wood 2001). With this in mind, we focus on the shifting narratives of women victimized by intimate partner violence and those around them. We link their identity projects to specific actions (i.e., staying or leaving an abusive relationship) and to narratives of others (e.g., children and abusive partners).

\section{Methods}

To understand how narratives of abusive relationships change, we rely on data from a photoethnography of people who use meth in rural Alabama in the United States. The larger aim of 
the project was to understand how people who use meth make sense of their lives and drug use in the context of rural poverty, including relationships. The primary part of the photo-ethnography spanned approximately 18 months (from summer of 2015 to winter of 2016). This portion of the project included interviews and appointment ethnography, where we scheduled times to come and meet with participants (Lindegaard 2018). We also remained in contact with a handful of participants after the primary fieldwork was done, which included follow-up photo-elicitation interviews (PEI) with this group. Formal interviews and informal observations were conducted with 52 participants. Participants were recruited first through a primary recruiter and then through snowball sampling to extend the sample beyond the primary recruiter's networks. The interviews took place in private homes (typically that of the recruiter or participants), public parks, or participant-chosen private locations. With their consent, participants were photographed, and some were asked to take their own photographs to send to the research team.

While we draw on insights gained from the broader project, here we focus on the photographs made of and offered by one participant-Misty—to illustrate how longitudinal ethnography can inform changing narratives of intimate partner violence. Misty was a part of the project for about a year and a half and maintained contact with us after the project was completed. We interacted with Misty at least twice a month during the project. During the project Jared took documentary photographs of Misty's life, including her husband JC, her children, and other family members. With her permission, we also captured screenshots of her social media pages, which included public fights with JC, photographs of her and her family, and posts detailing good and bad times with JC and her children.

In compliance with Institutional Review Board (IRB) approval, we obtained informed consent for all participants and informed them that the interviews were voluntary and would be kept confidential. The IRB approval included taking photographs of participants, having them send images to us, and downloading images from social media (all with participants' approval). All those who agreed to having photographs taken of them signed a release for themselves and for their minor children, if relevant. We made it clear that they could decline having photographs of themselves or their children taken and still participate in the study. Both Misty and JC consented to being a part of the study and to have their photographs taken. Misty also agreed to send photographs and to allow us to use photographs and other images from her social media accounts (e.g., Facebook). We only include photographs of Misty's minor children of whom she had custody (Michael and Michelle). In addition, we asked Misty, JC, Michael, and Michelle for approval to take photographs each time we visited them to ensure that they had not changed their minds after the initial consent.

We conducted four formal interviews with Misty (two were photo-elicitation interviews) and had dozens of informal interactions and conversations with her. In addition, she was present for a formal interview with JC. We audio-recorded all formal interviews with her and JC. These interviews were semi-structured and focused on themes such as her background, relationships with her family, her future aspirations, her drug use, and her relationship with JC. The first interview with Misty occurred late November 2015. This interview did not involve photographs and focused on her history of drug use and current life situation. The first photo-elicitation interview took place in July 2016. The second photo elicitation interview took place in early fall 2019, three years after the initial photo-elicitation interview. We included ten photos from the initial interview and ten new photos. The second photo elicitation interview was conducted on the phone. We sent photos through Facebook Messenger.

We acknowledge that the lenses through which we gathered and interpret the findings are influenced by our backgrounds and socio-demographic characteristics, as well as our personalities and current world views. The lead researchers (Heith and Jared) were White male professors 
(although a White woman student did accompany us on many occasions), which may have affected the way participants spoke and interacted with us. While the lead researchers' current social standing differed from those who took part in the study, their similar background (working class families from the South) and race appeared to help gain access to and develop rapport with participants.

Just as important for positionality is how backgrounds effect interpretation of the data. The analysis was conducted by the aforementioned White men from the Southern United States, who were directly connected with the gathering and production of the data, and a White woman (Lindsay). The latter was not a part of the original data collection. We believe the additional analyst, who was not a part of data collection, aided in looking for non-taken-for-granted knowledge of those most connected to data collection. Arguably, these varying backgrounds ensured that the data were probed in different ways by researchers from distinct research positions.

We include photographs here to provide context to the quotes and to draw readers into Misty's life. We believe that including photographs here will give insights into Misty's life and how she narratively makes sense of herself and her relationship with JC, but perhaps more importantly, the photographs will aid readers to be better able to connect with and humanize Misty and the others in her stories. We recognize the importance of interpreting photographs within their context as decontextualized images may have the unintended consequence of reinforcing negative cultural stereotypes (Becker 2007; Copes et al. 2019; Copes et al. 2017). Although we cannot control how readers interpret these photographs, we hope that the images will be interpreted within the context of the data presented. With this in mind, we have selected images that we believe reflect Misty's authentic experiences.

In what follows, we show how Misty's narratives of self and of JC are intertwined. The way she defined herself directly affected the way she defined JC. In the three years between the first and last interview, these narratives evolved from one where she saw herself as a "ride or die" wife who excused the abusive behavior of the man she loved, to one where she redirected her loyalty away from JC to her children. Subsequently, she portrayed JC as a poor father and terrible partner. We begin by detailing her initial narratives of self and of JC before moving on to the catalyst for change. We then discuss the changed narratives, showing how they were connected and changed concurrently. We argue that while the content of the narratives changed, she presents a unified story of self-as a loyal woman who looks out for her loved ones-and this story allowed her to break away from harmful relationships with men. Additionally, we show how the change in personal narrative necessitated a change in the narrative of JC.

\section{Initial Narratives of Self and of JC}

Misty's narratives of self and of JC were largely drawn from conceptions of traditional gender roles common in rural parts of the United States. Namely, these roles reflected traditional hegemonic masculinity and emphasized femininity. Misty described two personal narratives that made up core parts of her identity: One emphasized herself as a loyal wife and the another as a good mother. For JC, she drew on cultural narratives of traditional masculinity; namely, that he was a good provider and father for her children. These narratives allowed her to excuse JC's abuse while still portraying herself as a strong woman. These narratives implicitly support patriarchal notions of gender and in doing so may contribute to the normalization of violence and control. In this section, we only include data collected from the initial two interviews (including the first PEI) and from observations during this time, as these represent her initial narrative of herself and of JC. 


\section{Misty's Self-Narrative}

In her early stories of self, her loyalty to JC took precedence over her mother role, though the mother role was still highly valued. She spoke about her unwavering devotion to JC in a way that highlighted a fundamental characteristic of her personality-that she was a "ride or die" woman who valued being supportive of her man. "I can pray and pray for him every day, and God answers prayers. It may not be the time for him to change. It may take for him going to prison for him to even change. If that's what it takes ... I'll make it work with him. But right now he's still in my heart and I still fight every day for him."

This belief was reinforced by a slogan Misty and JC would say to one another: "If you ride, I'll ride. If you fight, I'll fight. If you die, I'll die." Misty said she would repeat this slogan during trying times with JC. Misty regularly reinforced this narrative of steadfast loyalty with social media posts. One example was a meme she posted: "I wanna stay with him no matter how hard things get. No matter what the struggle is, I wanna be able to make him smile." Her personal comment was simply, "I'm like that." Figure 1 was taken after JC had returned from a binge, and they were reconciling.

Misty valued her personal loyalty to such an extent that she stayed with JC despite his mental and physical abuse. When issues of his abusive behavior arose in conversations, she simply called forth the ride or die trope. One day she relayed a story of police looking for JC, who had been gone for several days. She said that he frequently would go on meth binges and disappear for several days and was likely with other women. When police came to find him, she lied about where he was. The police, knowing that she was not being truthful, asked why she protected him. Her reply to them was simply: "Because that's what we do." Figure 1 was taken soon after her returned from his binge. She said that despite him disappearing for days, she was still committed to him.

Figure 1: Misty and JC pose for a photograph at their friend/meth dealer's home, shortly after the couple had reconciled following JC's return from a multi-day methamphetamine binge. Photo by Jared Ragland.

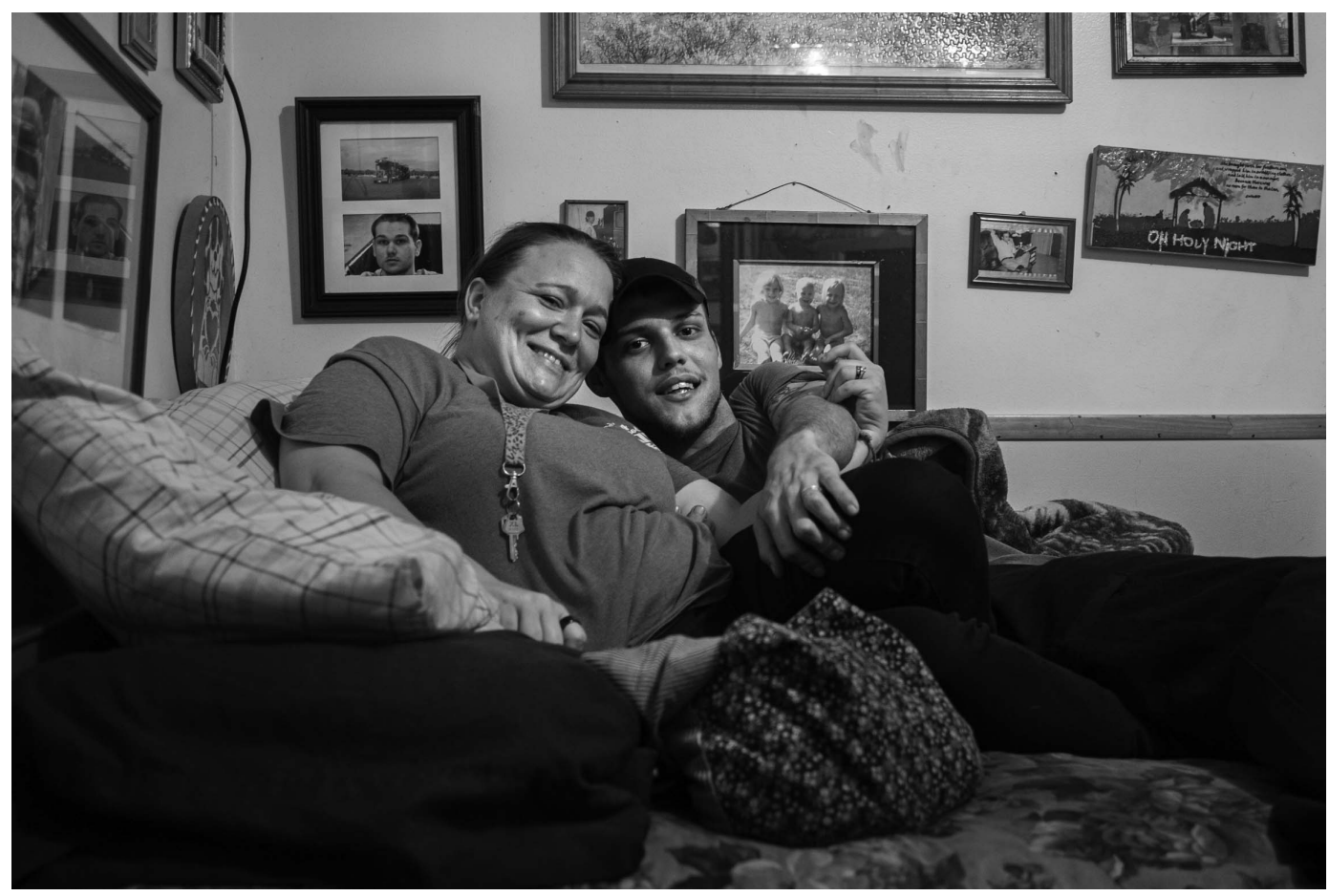


In addition to defining herself as a loyal wife, she also prided herself as being a caring mother. Prioritizing her children over drugs was important for Misty. In fact, much of her drug use was scheduled around being a mother. As she said, "I know I do drugs, but I know that I still have kids, and I still have to be here for my kids."

One way that Misty accounted for her drug use was by saying that she never used in front of her children and did not allow JC to sell when the kids were around. She said that she would do her best to keep meth out of the house, but when she did have it there, she would hide it. Misty said that it was difficult to abstain in the presence of her children, but her concern for her children's well-being prevailed, "When [Michael] is home during the week, I do fiend for it, but I look at him and be like he's worth way more than that." When she did use when her children were home, she would go to a friend's house who lived in a nearby apartment. Figure 2 shows portraits of her children going up the stairs, leading to the attic where she kept her meth and paraphernalia.

Another way she reinforced her role as a good mother was by ensuring her children were loved and cared for. Despite having little in the way of financial resources, Misty made her children's happiness a priority, even if it meant relying on selling meth to buy Christmas presents. She explained, "I sell the dope, I am trying to sell more now because my son's Christmas. I know that sounds wrong, shouldn't sell dope for Christmas presents, but you know that's the only way I can do it right now." Misty did make a point of recognizing the realities of drug use and making sure that her children were safe in the event they used drugs. She provided her children with some common-sense precautions, advising, "Don't ride around with it. Don't get caught. Make

Figure 2: Photographs of Misty's children line the stairwell of her apartment in Marshall County,

Alabama. Just above the stairway landing is an entryway to the attic where Misty would keep methamphetamine and drug-related paraphernalia out of the reach of her kids. Misty acknowledged that it was difficult at times to abstain in the presence of her children, but her concern for her children's well-being always prevailed. Photo by Jared Ragland.

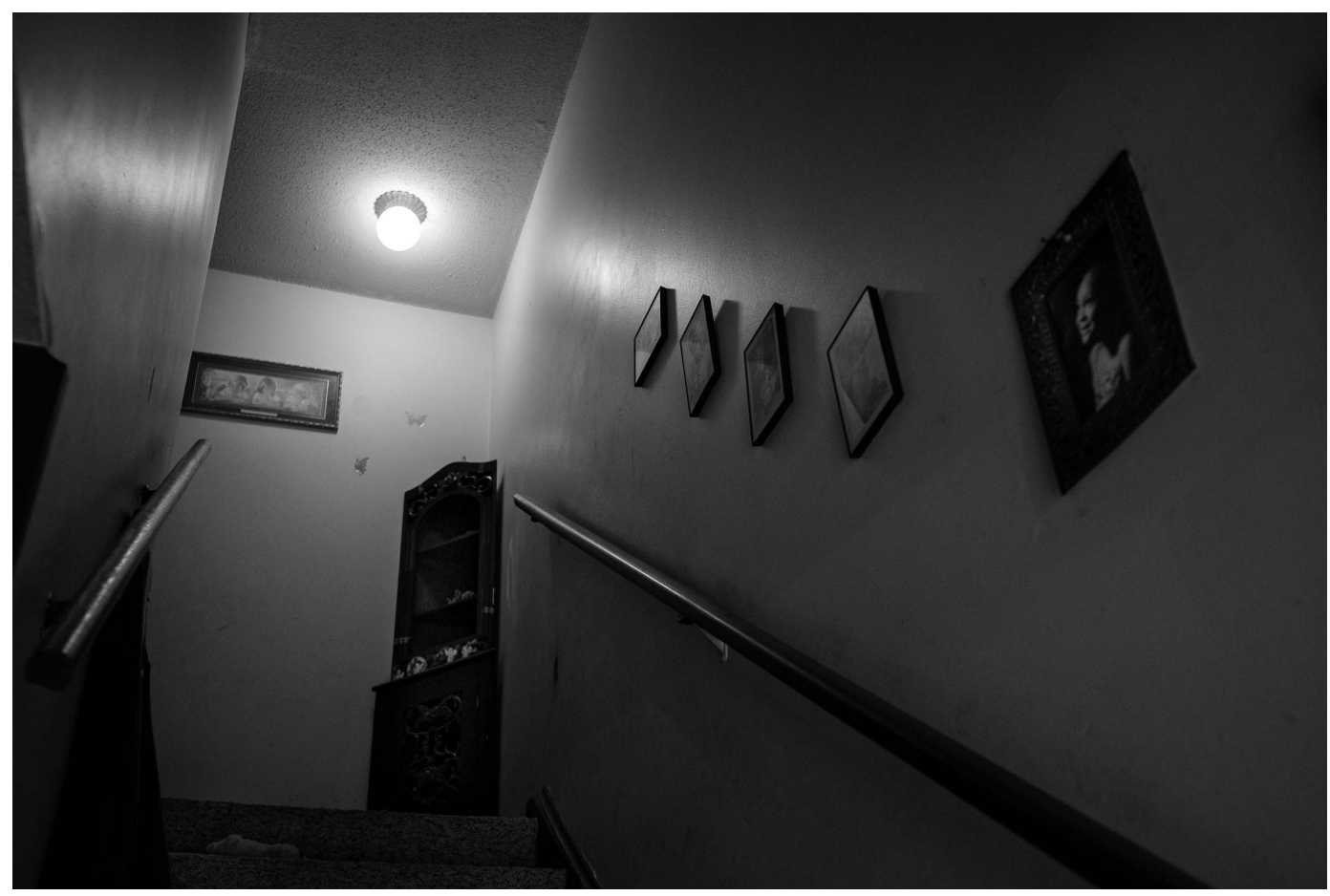


sure you're somewhere safe, where I know you're okay." For her, being a good mother meant not only teaching them best choices to make, but also ensuring their safety regardless of their decisions.

\section{Misty's Narrative of JC}

Just as people have personalized narratives of self, they also have narratives for people close to them. The narratives of friends also are drawn from larger cultural narratives and then made more complex and personal. Thus, Misty's narrative of JC drew from cultural themes of men being good providers and worthy fathers. Her depiction of him as a good man was tied closely with her own narrative as a loyal partner. She saw her loyalty as warranted because of his ability to be a good man.

Misty spoke of the deep connection they shared and saw using meth together as a vehicle to strengthen their bond. Instead of meth being a detriment to their relationship, she spoke of it as a tool that made their relationship better. She said they shared some of their best memories when they were high: "The last time he and I got high we got high five days straight together. You know, and I can tell you being high for them five days, that's the best part of my marriage I've been in with him. ... No fighting, no fussing, we spent every minute and second together. If he went somewhere, he pulled me right along with him. He didn't leave me there to sit by myself. I was every inch with him." Using meth with JC was an opportunity for them to focus exclusively on each other.

She described her bond with JC as something special, and even with JC away, she spoke fondly of the connection they shared when she called or visited him in prison: "While he's in jail I feel like we're right there. When he calls me now, I laugh so bad. When I go see him, we just smile and smile and smile so much. And he always tell me 'Just smile. Keep your head up, Lil Boo." Even via the phone or in brief visits, Misty saw her relationship with JC as something special and unmatched. When we showed her a photograph (see Figure 3), she said how much she loved and missed him: "I just want to be on him every second. I didn't wanna walk away from him. I wanted to cry the whole time. 'Cause I didn't wanna leave him. I miss him so much."

Misty's feelings for JC were based on two characteristics that she most admired in him: JC as a provider and JC as a good father. She drew on these narratives to understand and explain his behavior. Misty upheld traditional gender roles, seeing herself as the caring mother and JC as the good provider. These traditional gender roles shaped her early stories about JC and in part helped excuse his abuse. During the first photo-elicitation interview, we showed Misty a photograph of her on the phone (see Figure 4). She had returned from court and was looking for JC. Worried that he may be in jail, she stood in the parking lot of her apartment and called the local jails. She had not seen JC in several days before this. She said:

I'm just happy when he's home. I really am.... It's like when he goes to jail, I lose everything. But when JC's home, he makes it happen. He makes sure the lights paid, we have food, we have home, we have somewhere to go. When he goes to jail, I lose everything. I don't know if that's a good thing or a bad thing. But I think of JC as my backbone. He tells me all the time you're gonna stay strong, keep your head up. That's what he keeps telling me, keep your head up, Misty you can do this. But it's hard doin' it when you're used to having him do it the whole time for you.

In lamenting over JC's absence, Misty emphasized his role as a provider on whom she could depend. In her eyes, JC's support was irreplaceable. Such a sentiment is common among abused women who believe they cannot make it on their own without their partners (Ferraro and Johnson 1983). 
Figure 3: JC and Misty share a kiss as bite marks can be seen on JC's neck. Misty described her bond with JC as something special, and fondly spoke of the connection they shared. "I just want to be on him every second," she says. Photo by Jared Ragland.

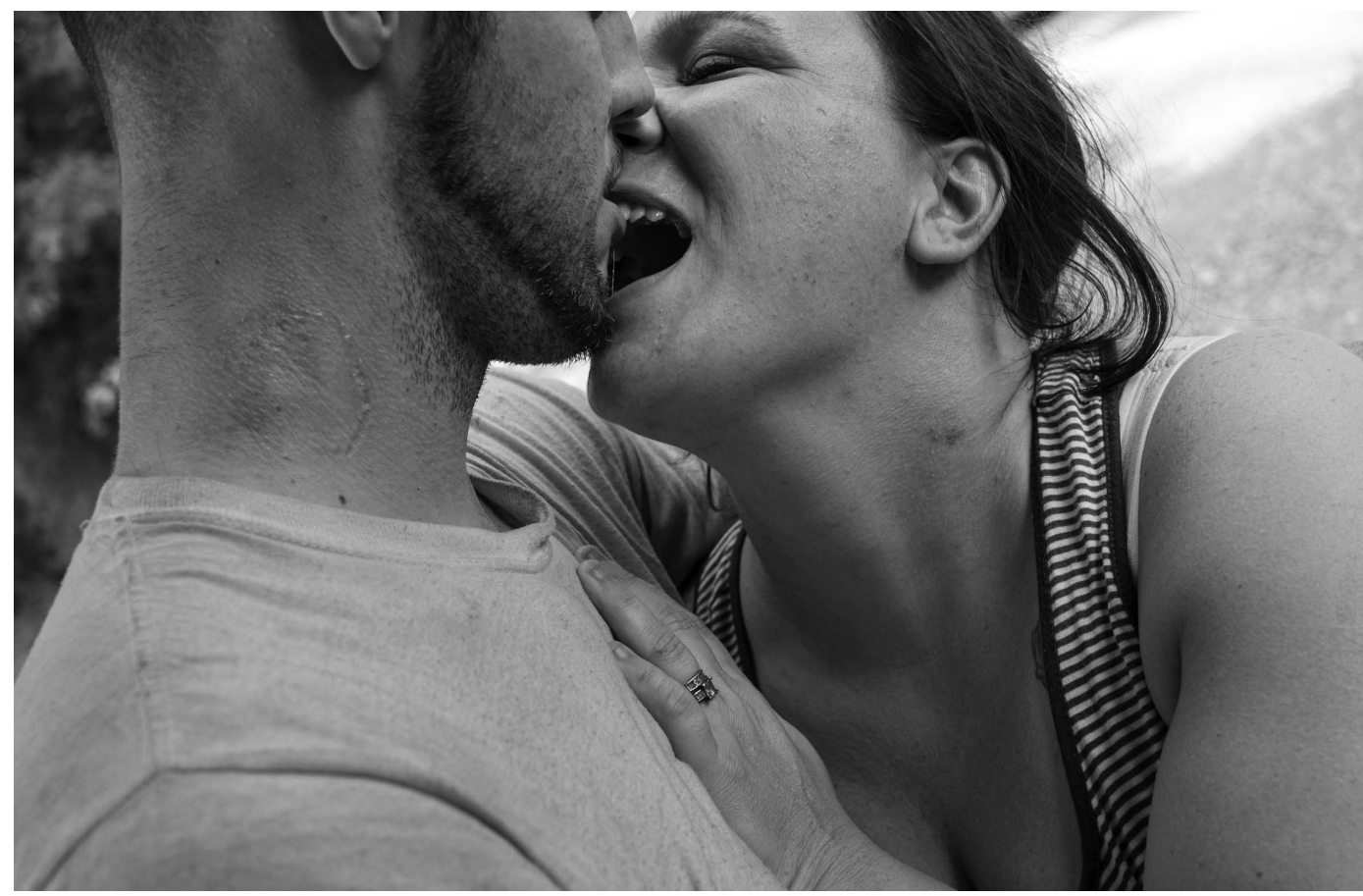

Figure 4: Misty makes calls to local jails in search of JC, who had been missing for several days after he took Misty's children's Christmas presents to sell in exchange for methamphetamine. "When JC's home, he makes it happen," Misty says. "He makes sure the lights paid, we have food, we have home, we have somewhere to go. When he goes to jail, I lose everything." Photo by Jared Ragland.

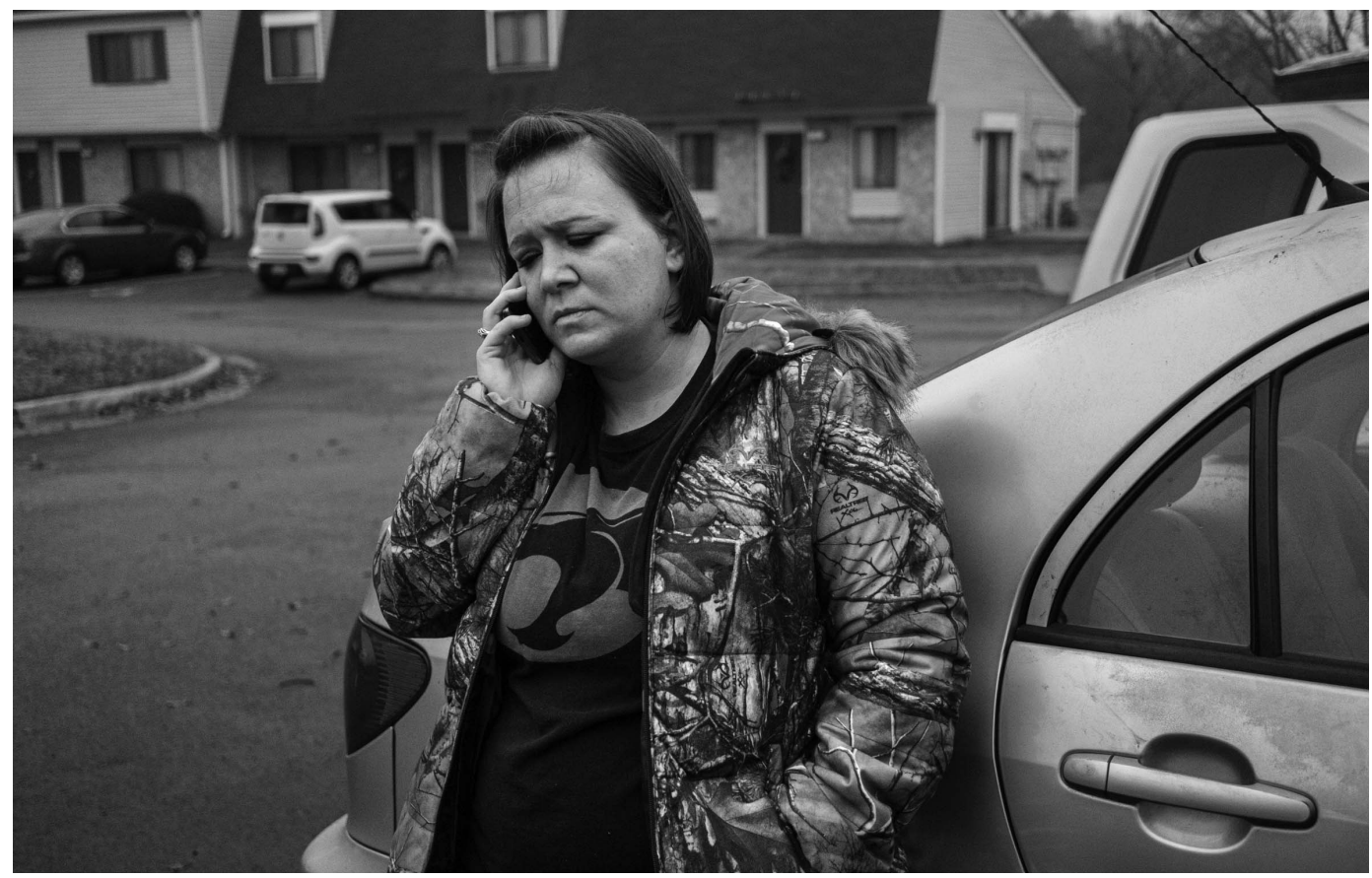


Misty described JC as a good father for her children. She regularly mentioned how JC fully accepted her children and treated them like they were his own. She made a point of mentioning that it did not matter to JC that her children were biracial, noting that many men in the area would not so willingly accept biracial children. To reinforce the bond JC had with Michael, she proudly told us, "Michael calls him his daddy." In describing Michael, she said, "He sees the daddy role model, the man role model, or something he wants to be when he grows up." Figure 5 shows Michael dressed in JC's work clothes. When discussing the possibility that JC could leave her son's life due to incarceration, Misty commented, "It's going to hurt [Michael]. He loves him. He hates his real daddy. JC's been there and he's raised him and that's who Michael wants to be, just like him."

\section{Excusing Abuse}

Misty told many stories of JC as a fun-loving, positive figure in her life. However, she also told stories that portrayed him as abusive. Misty drew on her narratives of being a loyal wife and of JC being a good man to excuse this abuse. These instances of abuse were often downplayed by either denying any real harm, claiming it was just the nature of relationships, or saying it was the results of the meth use and not his true self (Ferraro and Johnson 1983). When discussing a photo that she had taken of bruises on her neck, Misty described a fight with JC brought on by accusations of her of cheating on him. When she denied these accusations, she told us, "He grabbed at my throat and I tried to pull away he kept grabbing tighter and tighter.... One of my ribs was cracked where he stomped me."

Figure 5: Misty's son Michael tries on JC's hard hat and safety vest during a visit to JC's prison work release job. Even though JC was not Michael's biological father, "Michael calls him his daddy,"

Misty says. "He sees the daddy role model, the man role model, or something he wants to be when he grows up." Photo by Jared Ragland.

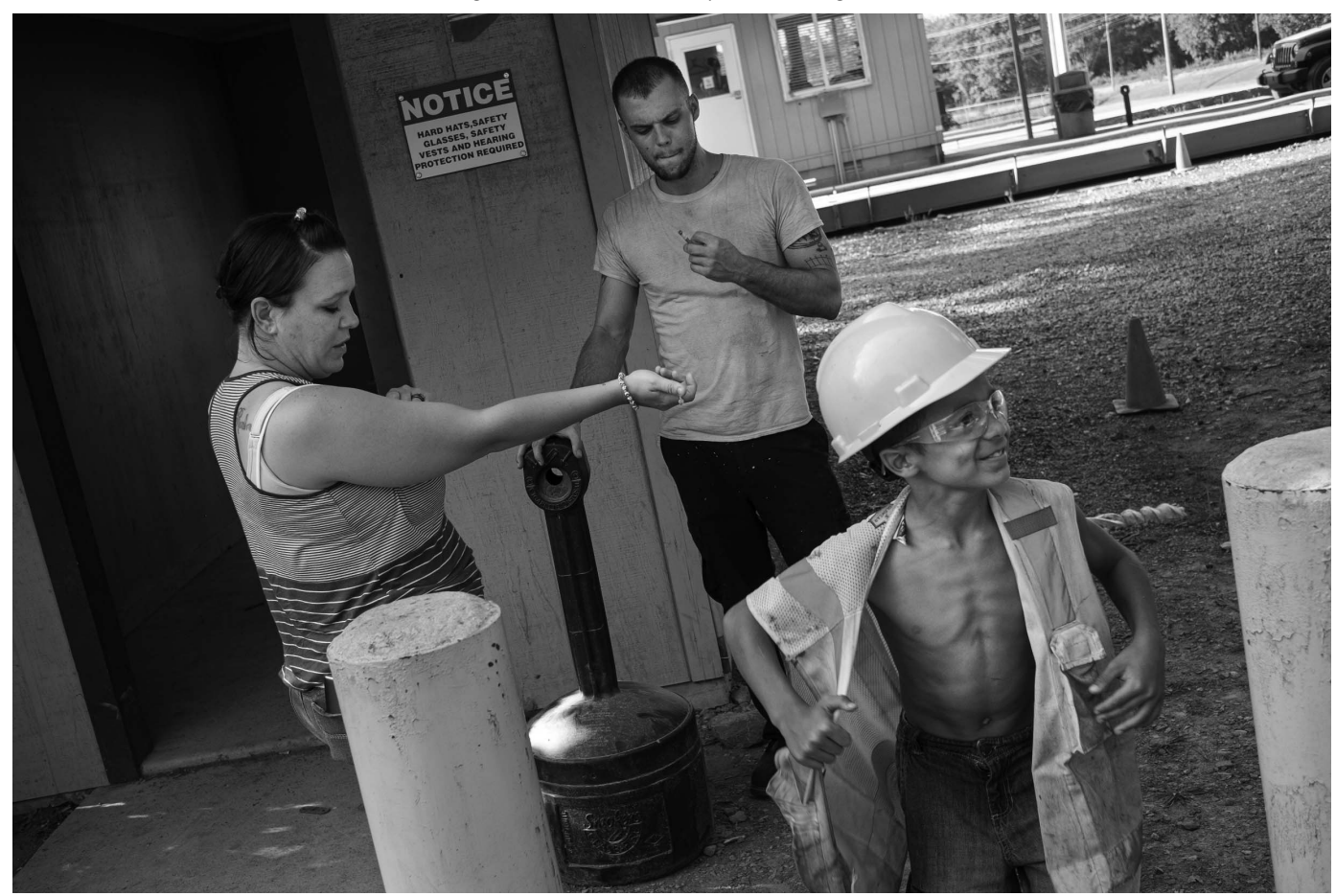


In the face of this violence, Misty considered leaving JC. However, she said she found reasons to stay. One of the most frequently mentioned rationalizations for staying was that she believed these behaviors were not the "real" JC. Instead, these behaviors came about because of meth and she did not want to abandon him when he needed help: "Afterwards when he sees my face and the black eye, he gonna start apologizing and start crying. And I realized then, you know what, I gotta go... . I tried to run from him but something wouldn't let me go. I don't know what's holding me back to him. 'Cause I know when he's not high and when he's not on drugs, he's a good person. And if I can get that person out and get him off drugs, we'd have the best marriage ever."

Although she acknowledged the abusive episodes, Misty drew on the narrative she had constructed of JC to remind herself that he was indeed a good person with whom she shared a deep connection. She often placed the blame on meth use rather than on JC's personal character, which allowed her to deny that JC was a victimizer. She explained: "JC mixes his [meth] with pills and stuff and it makes him violent. You know I've carried a lot of black eyes and knots on my head being beat up with him with doing that. But I still took him back because I know that's not JC. When JC is sober, he is the best man."

Misty held onto her positive narrative of JC for many years, saying that he was "the best man" when sober, and that drug use brought out a different person in him. When asked directly why she stayed with him, Misty expressed her attachment to the relationship, replying "I wanna say love, but I don't know what it is."

She described her dedication to JC as a part of maintaining traditional gender roles-a key part of her loyal wife narrative: "Everyone always says, 'Oh, it's your husband, it's your husband, it's your husband, you gotta give him [a chance].' And they're making me think, 'Oh, you gotta stay with this person forever.' Everyone always speaks that in my head, even the church."

Misty had internalized these expectations of being a dutiful wife and made them a part of her self-narrative. Even when others spoke out against JC, she drew on her narrative of a loyal wife to resist their opinions. She recalled a conversation in which her mother cautioned, "One day JC is gonna turn, Misty, and you ain't gonna be here no more." She responded, telling us: “Ain't nothing I can do. If I'm dead, I'm dead. At least I see it this way, if I die, how would I see that, I know that my son's gonna be taken care of. I know that for a fact. I don't wanna leave his life, I don't, but how do you stop loving somebody?"

Even when her mother brought up JC's abuse, Misty relied on her narrative of being a loyal wife to describe unwavering love for JC and her unwillingness to leave the relationship. She spoke of being proud that she was loyal and was there to help him.

Misty's narrative of herself was intertwined with her narrative of JC. Misty's perception of herself shaped her perception of JC and vice versa. She saw herself as a dutiful, loyal partner to someone she saw as a loving provider. She viewed JC as a good father, reinforcing her view of herself as a good mother by virtue of involving a good father figure in her child's life. The interlocked nature of these narratives allowed her to make excuses for JC's abuse.

\section{Catalyst for Change}

Change is a key component of narratives. It is the change in circumstances or context that allows for change in self narratives to be seen as consistent. Thus, many narratives highlight specific moments or events that lead to new perceptions of self as well as new perceptions of others. Women who eventually leave abusive relationships often point to changes in opinions of others, in the harm done by the abuser, or in the victim's circumstances as the turning points or catalysts for change (Brosi and Rolling 2010; Ferraro and Johnson 1983). Misty said that her perspective 
of self and of JC changed when there was a clash between her two key narratives of self: her as a good mother and her as a loyal wife. Misty expressed several reasons for this change, including JC becoming violent toward her children, moments of insight from Michael about JC's abuse, and her simply seeing what she called the ugliness of the lifestyle. ${ }^{1}$

A pivotal moment happened after his release from jail when JC's abuse spread to her son. It is often when abuse spreads to children that women seek to leave the relationship (Ferraro and Johnson 1983). Misty described responding angrily to the incident: "He punched Michael in the mouth. Michael punched him, but he was a grown man. [Michael] told JC I'd cut his throat, I didn't give a damn about going to prison over him. I still feel the same today. I'd go to prison over that little eight-year-old there, that's my life."

In the face of JC's violence toward Michael, Misty's narrative as a mother won out over her narrative as a loyal wife to JC. She said that she could handle the abuse herself when it did not directly involve her children. Once JC began physically harming her children, however, she began to no longer excuse his actions and her story of herself and of JC shifted.

Her change was not immediate. It was a series of events, including remarks from Michael, that helped lead to a change in her narratives. She recalled the first remark that made her start to rethink her priorities: "Michael said, 'Mamma, when you get married, you don't marry a man that hurts you.' And I said, 'What're you talking about?' He said, 'Daddy hurts you.' And I said, 'Yeah, he hurt my feelings.' 'No, Daddy hurt you. That's not how a marriage works."'

This moment served as a trigger, and she began to rethink her sense of self. After showing Misty a photograph of Michael in a mask (see Figure 6) she recalled an exchange with him that was particularly meaningful for her: "What made me really, really leave JC, well my son looked

Figure 6: Misty and her son, Michael, 8-wearing a Mexican luche libre wrestling mask-play in front of their apartment in Marshall County, Alabama. "Michael, that's my little hero-that's the one that keeps me going right there," Misty says. "He'll fight an army for me, man. I've seen him do it." Photo by Jared Ragland.

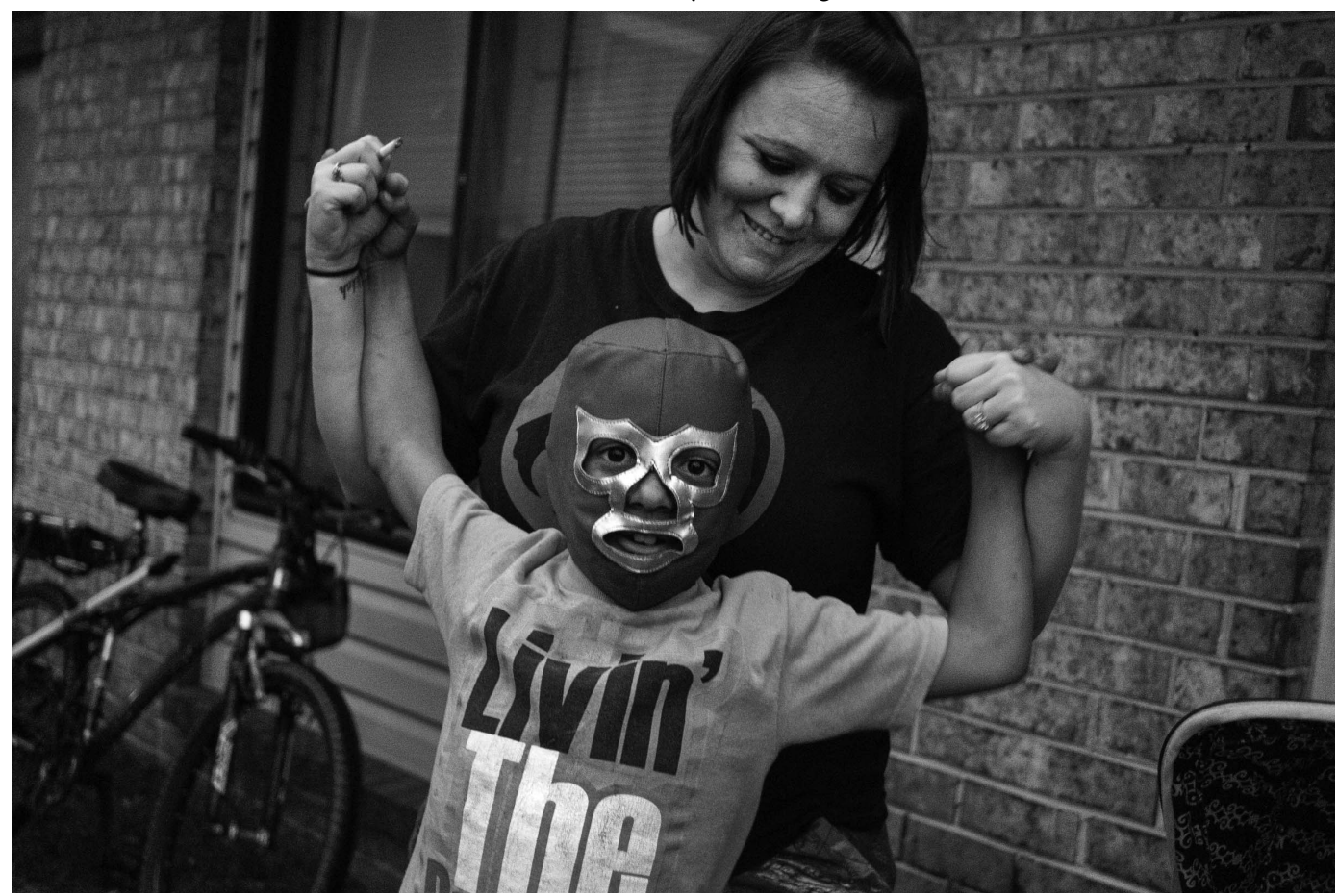


me in my face and told me 'One things that gonna kill you is you gonna die by JC's hands.' I had to get out. He saved me, he's my little hero."

JC's abuse of Michael and these words from Michael became the catalysts for Misty's change in her personal narrative and in her narrative of JC. She took great pride in being a mother. Hearing these words from Michael made her reconsider what being a good mother really meant. As she said: "I wanna be something my kids are proud of. It's better than saying, 'Oh, my momma was a drug addict' or 'My momma lost us cause of drugs.' I've made a lot of mistakes. You do better and you want better, do it for yourself and for your loved ones." These instances exposed a contradiction in her two narratives, whereby Misty realized she was unable to be a "ride or die" woman for JC while also being a good mother.

The role of Misty's son in her changing narrative reflects prior work suggesting the importance of children in redefining and leaving an abusive situation. One important catalyst for change is how others (particularly children) respond to and define the abuse and leave an abusive situation (Ferraro and Johnson 1983). This process of leaving may be amplified by others' expressions of empathy with the victim (Meyer 2016). Although we can identify that Misty saw Michael's comments as the primary catalyst for change, we acknowledge that we are unable to say whether Michael's comments led to change in how she saw JC or in how she saw herself. Regardless of which narrative changed first, their intertwined nature determined that the other one changed as well.

\section{Changed Narratives of Self and JC}

Misty described her change as coming from Michael's fears about her safety. It is not possible to determine if this event was the precise factor that led to her change or if it was simply an event that Misty used to construct a rational narrative of change; narratives are too flexible to make such a determination. These two narratives were so entwined that a change in one necessitated a change in the other. She no longer saw JC as a good father figure for her children and having JC in her life prevented her from seeing herself as a good mother. Thus, Misty's rejection of the narrative she constructed of JC helped her reject part of her narrative of self. As both narratives began to change, so too did her excusing of JC's abusive actions. These narratives were told to us during the second PEI and other informal interactions around that time, which were three years after the first PEI.

\section{Subsequent Narrative of JC}

Misty moved from a supportive narrative of JC where she explained away his abusive behaviors to one where she placed blame directly upon him. Her stories of him being a good provider, lover, and father shifted to ones that defined him as toxic, dangerous, and a harbinger of bad things. When we asked her to send an image that she believed represented JC she sent one of a shadowy, dark, demon. She simply said, "JC is death."

One of the biggest changes in her narrative of JC was in how she spoke about him being a positive role model for her children. This narrative shifted focus from JC as father to JC as drug user. Where she once portrayed JC as a good guy who was turned bad by drugs, she began to portray him as choosing drugs over her and the children. One story she told highlighted his obsession with meth:

We had no water, no power. Run outta food. Michael had no shoes. JC, who gets his check in the mail, wants me to go cash it and go buy him some dope. It's more about Michael's shoes. 
[JC said], "He'll be okay, he don't need nothin." So I went and cashed the check and I still bought Michael shoes. I got beat for it. Michael jumped up and told him, "You don't beat my momma! Don't do that! Don't do that!" If my kid saw it, but I was blind to it, you know I had to leave. I ain't looked back, and it's been two years.

This narrative told of JC as choosing to use drugs and choosing them over the family, rather than a passive victim of drug use. This new interpretation of JC's actions disconfirmed the narrative she had constructed of him initially. He was no longer a good provider or a good father figure. He was now a selfish man who put the children in harm's way. This new story highlighted both her new narrative of JC as being solely controlled by drugs and her heightened emphasis on being a mother and respecting her son. When we showed Misty Figure 7 she said that is how he is now, solely focused on his drugs.

In light of the new narrative she had constructed of JC, Misty described seeing him as a new person entirely. "I guess I was blind. You how they say love is blind, you don't see the real person? And I guess after all the abuse, I couldn't be around the real him." When we asked her who the "real" JC was, she said, "He's a woman beater, he's a drug addict. He don't care, he only cares about himself, about getting high. He don't care about life. He's selfish." Such sentiments differ considerably from her earlier depictions of his real self as a good person made bad by drugs.

While she previously emphasized her devotion to JC and their strong love, Misty began to talk differently about their prior intimacy. She no longer described their previous sex life as exciting, positive, and loving. She now described it as being "just like street sex, like prostitute sex." She now viewed the times they were together as perverted and a product of meth use. No longer seeing JC as a good man or lover, she now portrayed him as a sexual pervert. In rejecting the previous narrative of JC as a good lover with whom she shared a strong intimate connec-

Figure 7: JC, high on methamphetamine, weighs out a bag of "ice" in the floor of his living room. Photo by Jared Ragland.

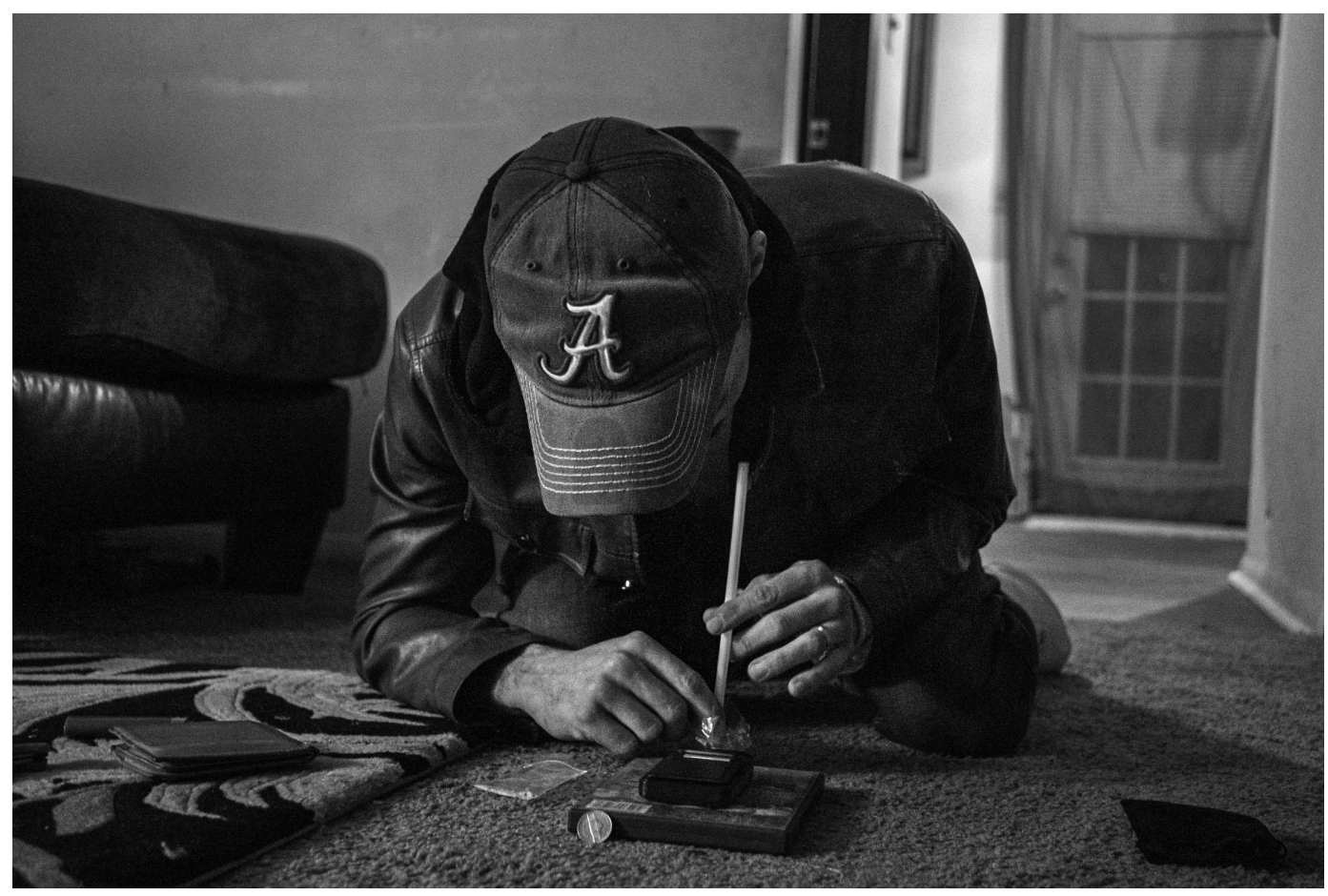


tion, Misty now reframed her relationship with JC as a dark part of her past, one in which she engaged in behaviors she now viewed as uncharacteristic of her new, "real" self.

\section{Misty's Subsequent Self-Narrative}

Misty began to reject her former self and construct a new narrative that was in direct opposition to her former narrative. No longer did she have unwavering devotion to JC; she now was devoted to her children's well-being and happiness. No longer was she dependent on him as a provider; she now emphasized her own independence and self-sufficiency. No longer did she continue to use meth; she now remains drug free to be available (mentally and physically) for her children.

Whereas before she saw herself as someone who would prioritize her love of JC above all else, Misty now saw herself first and foremost as a nurturer for her children. When asked to provide a picture that reflected how she felt about herself, Misty sent us a painting of a large tree with deep far-reaching roots and explained: "The tree represents me, the roots and all that growing is, I can't explain it. If I stay alive, the tree stays alive and the roots are gonna keep growing. . . . Trees have a lot of seeds and the seeds regrow more trees and more life and I feel like, I got a lot of kids. So, I've made life, and the tree is responsible for feeding them and that's how I feel. I'm the tree of life and I gave life. I breathe for my kids and the tree breathes for the roots." Misty's role as a mother was central to her new narrative of self. She talked about thinking of the tree image often and reminding herself, "The roots depend on the tree, and my kids depend on me now." She spoke fondly of a photograph of her children playing in a tree (see Figure 8) and how she was there for them.

Figure 8: Misty plays with her children, Michael and Michelle, in the backyard of their home. "If I kept doing what I was doing I was going to end up dead, and I wouldn't know, like, who's gonna take care of my kids," Misty says. "My kids needed me. I knew I had to do something.

I had to step up. I wasn't being no mom." Photo by Jared Ragland.

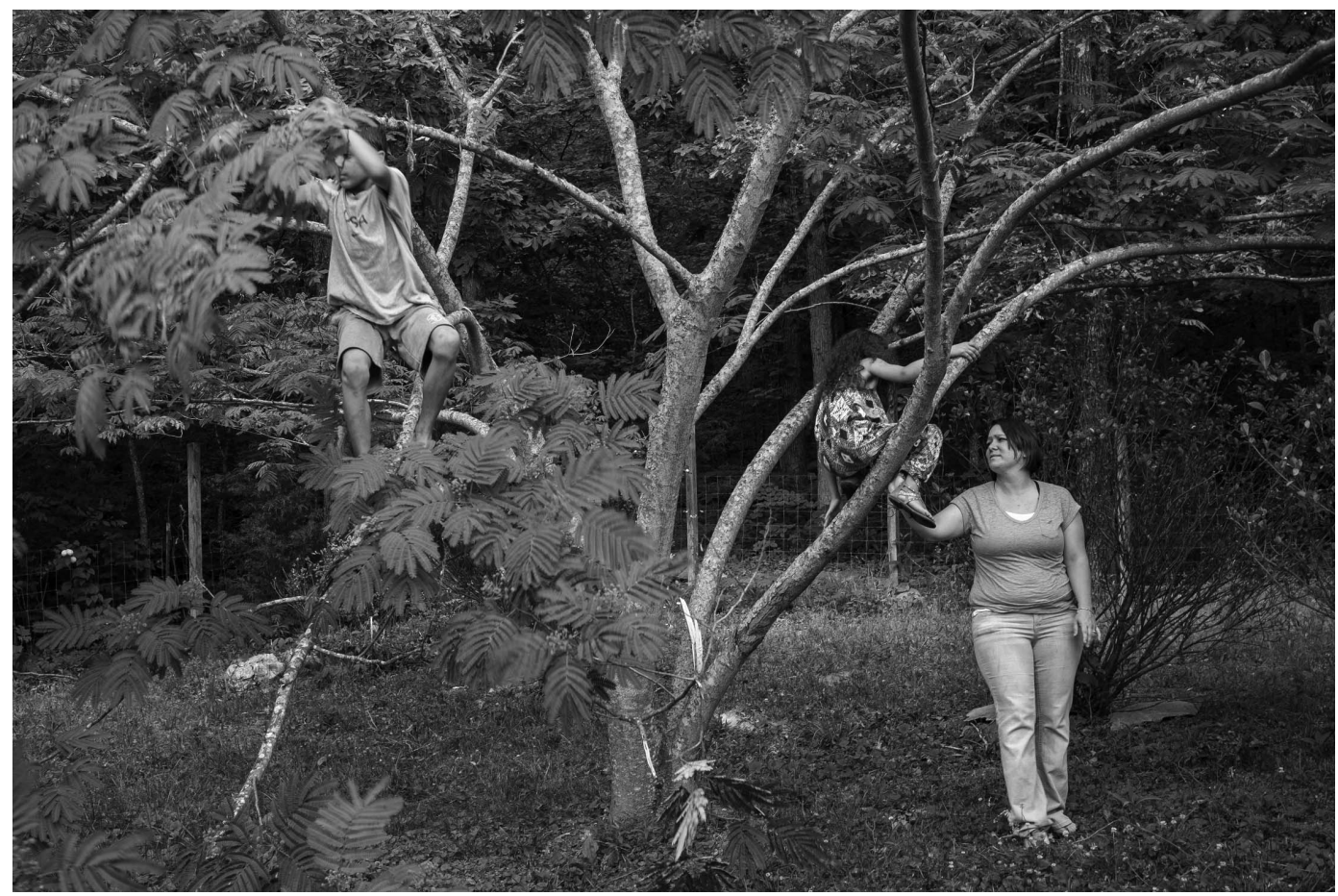


She highlighted her dedication to her kids by contrasting this with that of her previous behavior, "If I kept doing what I was doing I was going to end up dead, and I wouldn't know, like who's gonna take care of my kids? My kids needed me. I knew I had to do something. I had to step up. I wasn't being no mom." She explained, "I would make sure that I was high before my kids got a new outfit. I would make sure I was high before my kids had school supplies." She described her current behavior in contrast to the past, "Now, I do without to make sure my kids have everything." She proudly described the steps she took to be a good caretaker for her children: "I do my payments first, my car is paid first, there's food in the house before anything, Michael has every school supply. He's in fourth [grade] now and Michael will not wear Walmart clothes anymore 'cause he's grown. He thinks he gotta wear these Under Armor clothes, and so I make sure I work these extra hours, and make sure that he's got it." Misty now saw her role as a mother as central to her newly constructed narrative of self. While she drew on tropes of motherhood to describe herself initially, she now said that she is truly doing so now.

A dominant aspect to Misty's previous narrative was her dependence on JC to provide for her and Michael. In rejecting this idea of JC as a provider, Misty began to frame herself as someone who was independent, strong, and self-sufficient. These beliefs reinforced her idea of being a good mother who could provide for her children. She said that she now had new mindset. "Leaving JC and being with him is like two different worlds," she explained. She began holding a steady job and re-established a relationship with her oldest son. During our final interview with Misty, she spoke about her new boyfriend, Wayne. She told us, "He said I can stay home and he'll take care of me." She proudly insisted, "But I want to work." Maintaining her own independence and self-sufficiency was important to Misty's changed narrative of self.

Recognizing one's self-worth is important for recovering from abusive pasts (Meyer 2016). Misty now spoke of her own worth. As she said, "I deserve to be happy, 'cause I wasn't happy." This new understanding helped her see herself as someone who could be independent. She elaborated, "I feel alive now and I wasn't alive. I guess now I can say that my life was dead with him, going nowhere." We asked Misty to send an image reflecting how she now felt about herself. She sent an image she found on the internet of a young woman in an open field of flowers with her arms raised. She elaborated, "I feel free. I feel like a child is, they have no worries and no fears. That's how I feel. I have no worries or fears no more. . . I'm living, I'm alive. I'm living, I'm blessed."

While she previously depended on JC as a source of strength, she now turned to her children. Talking about Michael, she said “He was strong. I wasn't. I was weak. I didn't even know I was weak then, but I was." She now focused on the central role of her children in getting her through hard times. Reflecting on the photograph of Michael in a luchador mask (Figure 7), she said, "Michael, that's my little hero, That's the one that keeps me going right there. ... Yeah, he'll fight an army for me, man. I've seen him do it." Similarly, she shared these sentiments on social media, posting pictures with her children with the caption, "Me Knowing that I got People counting on me ... keeps me motivated every day!!! The reasons for my strength, happiness and will to keep going."

\section{Rejecting Abuse}

Equipped with these new narratives, Misty now rejected abuse and poor treatment from JC and others, leading to their separation. She said that after she left him, JC made numerous attempts to come back, often pleading publicly on social media for her to take him back. Misty rejected his pleas. Although the divorce is not yet final, she no longer has any interactions with JC. 
Misty began dating another man, Wayne, after they separated. When they first began dating she spoke fondly of him and pointed out his positive traits (e.g., his ability to provide and be a father and that he did not use meth). When we asked her what would happen if Wayne began being abusive and using meth, Misty emphatically responded, "I would have to leave. I don't want that life again. Wayne, like, I love him, I do, he has me spoiled rotten. But, I'd rather do without in life than to have to go through that again."

After they dated for several months, she learned of Wayne's potential infidelity. This new identity as a strong woman who prioritizes her children over men led her to immediately confront the issue. She did so publicly, posting a message on social media.

The truth was bound to come out and I won't and will not be played by anyone. . . I I warned you if I found out different that I would walk away and never look back!!! So as of now I'm walking and wishing you the best because I was fine before I met you and I'll be just fine still without ya bruh!!! . . . If I stay then what am I teaching my daughters??? I won't teach them that it's ok to let a man use them or never be enough for a man because I am enough and I know my daughters are way more then enough!!!

This public statement emphasized how her new identity would not allow her to be weak or to act as a poor model for her children, in this case her daughters. Her new sense of self contributed to her response to his infidelity.

Misty now sees herself as a different person than she was back then. We shared a copy of the manuscript to get her thoughts on it. Her reply (through text) reinforced her narrative as a new woman: "All I can say after reading all that, is that love is blind and it can control you and make you do the stupidest things!! I've learned from my mistakes and it's a lesson learnt!! I live and I'll die for my kids now!!! At the end of each day I know I can come home from a long day of a real job to my kids and feel unconditionally love that I will never have with anyone else!! They're my true ride or dies!!!!”

People must make sense of dramatic life changes in ways that ensure a stable, consistent view of self (Sandberg 2013). Those who desist from drugs often make sense of their desistance by pointing to an old self (who was controlled by drugs) and a new or real self (who is free from the control of drugs) (Maruna 2001). Women in abusive relationships make sense of their leaving by telling of changes in situations, victimization, or reactions from others as the impetus for leaving (Ferraro and Johnson 1983). For Misty, the changes in narratives meant explaining why she remained with JC despite his abuse, and eventually left, and how those connect to her new narrative of self.

\section{Discussion and Conclusion}

Narrative approaches allow researchers to explore how and why people construct stories, and what their stories tells us about how they make sense of their experiences and decisions. We combined a narrative framework with longitudinal photo-ethnography to explore how one woman-Misty - made sense of her narratives of self and of her abuser. Our longitudinal photo-elicitation approach enabled us to assess how Misty's narratives changed, and to pinpoint her explanations for this change. Our findings point to the importance of narratives in understanding how people make sense of staying with abusive partners, how they change their perceptions of abuse over time, and how their perceptions of others play a role in those changes, and how these processes can guide decisions to leave. 
Misty's initial narratives emphasized her desire to be a loyal wife and good mother, and her perception of JC as a good provider and father. These narrative understandings of herself and JC provided the foundation for excusing JC's abuse (e.g., he was a good person who was changed by drugs, and she wanted to be there for him). In constructing her narrative of self, Misty drew on broader cultural themes from the context of rural areas in the Southern United States about what it means to be a woman, mother, and wife. She emphasized cultural narratives of women as being loyal and faithful to their husbands to excuse JC's behavior without seeing herself as a victim. These cultural narratives allowed Misty to have a strong sense of self-as a ride or die wife-while remaining with him. Her early narratives are implicitly supportive of patriarchal ideas of gender and in ways normalizing violence and control from men as a means of enacting masculinity. Such narratives are common among women who stay in abusive relationships (Ferraro and Johnson 1983; Lim et al. 2015; Meyer 2016; Weiss 2011).

Eventually, Misty's narratives shifted. Again, she drew on larger cultural narratives of motherhood to make sense of these changes. Misty used her son Michael's confrontation about the danger of remaining with JC as a turning point for her narrative, shifting her narrative to one that prioritized motherhood over being a loyal spouse. Equipped with her new self-narrative, Misty no longer made excuses for JC and refused to accept his abuse. She began to see herself as a devoted mother who sacrificed to protect her children, and as an independent woman who could care for herself and her children. Describing Michael as the catalyst for change enabled Misty to provide a clear, unified story as a strong woman and devoted mother.

It is also important to note that the narratives Misty presented portray a clear story of change. This is likely a product of the three-year period between photo-elicitation interviews (and four years from initial interview), where Misty went from living with JC to no longer living with him. We would have seen a less seamless combination of narratives and actions if we had analyzed the period in between interviews, when Misty's narratives were still developing. Indeed, Misty described leaving JC as a process where she often doubted herself and went back to him. Nevertheless, the narratives and narrative shifts presented represent the finalized, clean story that Misty constructed to make sense of her personal change.

Although often painted as trapped and powerless (Dunn 2005), those who experience of intimate partner violence can be resilient in the face of traumatic experiences, rather than merely being passive actors lacking agency (Westphal and Bonanno 2007). The narratives Misty created, both of herself and of JC, functioned to help her make sense of her relationship and abuse. Misty emphasized her empowerment in both her early and later narratives of herself. Though she suffered violent victimization at the hands of JC, she did not portray herself as a victim in her initial narrative of self. Instead, she gained a sense of empowerment from her personal narrative as a strong and dutiful wife. Indeed, Misty's sense of power in her initial narrative enabled her to stay in the relationship. However, Michael's words served as a catalyst that led her to rethink how she defined herself and how she thought about empowerment. She then strove for empowerment in a new way in leaving the relationship and becoming independent. In her later personal narrative, Misty also constructed herself as empowered, emphasizing her ability to be independent and to take care of herself and her children on her own. While she later came to see herself as a victim in the past, she did not construct herself in such a way at the time. This suggests that victims of intimate partner violence find ways to emphasize their agency and empower themselves through narratives.

Our findings have implications for understanding how women experiencing intimate partner violence rely on a series of narrative understandings of themselves and their abusers to make sense of their experiences and actions. We also shed light on how people's narratives of themselves and others are connected. Narratives are not constructed in a vacuum; rather, people 
use their narratives of others to make sense of themselves and use narratives of themselves to make sense of others. This co-construction of narratives of self with narratives of others speaks to the importance of change in multiple narratives in leaving abusive relationships. Change in narratives of self and those of close others (e.g., loved ones) often correspond, and change in both narratives may guide action (i.e., leaving). Misty's narrative of self and of JC changed concurrently. By changing her narrative from primarily a loyal partner to one of caring mother, she shifted her narrative of JC to that of a dysfunctional user and bad father and ultimately decided to end the relationship. Considering the interconnected narratives that those who experience intimate partner violence construct of themselves and of their abusers provides important insight in understanding their decisions to stay and leave abusive relationships.

HEITH COPES is a professor in the Department of Criminal Justice at the University of Alabama at Birmingham. His primary interest is in understanding the decision-making process and identity construction of people who engage in crime and drug use. Email: jhcopes@ uab.edu

LINDSAY LEBAN is an assistant professor at the University of Alabama at Birmingham. She received her PhD from the University of Florida in 2018. Her research interests include gender and offending, victimization, substance and drug use, and criminological theories. Email: leleban@uab.edu

JARED RAGLAND is an Assistant Professor of Photography at Utah State University. He is a 2020 Magnum Foundation grantee, 2020-21 Do Good Fund Artist-in-Residence, and served as a White House Photo Editor under the Bush and Obama Administrations. Email: jared@jaredragland.com

\section{NOTES}

1. During a follow up interview, we asked Misty what made her quit using meth. One reason she mentioned was taking part in the interviews. As she said, "Doing all these interviews ... I would see what it looked like and I would be so disgusted by this. ... After all these interviews I've done with y'all and me taking you to [people's] houses and ... I thought, 'Do I live like that? Do I look like that?' You know? 'Cause I'm just like, it's disgusting me."

\section{REFERENCES}

Becker, Howard. 2007. Telling about Society. Chicago: University of Chicago Press.

Brosi, Matthew, and Emily Rolling. 2010. "A Narrative Journey for Intimate Partner Violence: From Victim to Survivor." American Journal of Family Therapy 38: 237-250.

Copes, Heith, Whitney Tchoula, Fiona Brookman, and Jared Ragland. 2017. "Photo-elicitation Interviews with Vulnerable Populations: Practical and Ethical Considerations." Deviant Behavior 9: 475-494.

Copes, Heith, Whitney Tchoula, and Jared Ragland. 2019. "Ethically Representing Drug Use: Photographs and Ethnographic Research with People Who Use Methamphetamine." Journal of Qualitative Criminal Justice and Criminology 8 (1): 21-36. 
Dunn, Jennifer. 2005. "Victims and Survivors: Emerging Vocabularies of Motive for Battered Women Who Stay." Sociological Inquiry 75 (1): 1-30.

Ferraro, Kathleen, and John Johnson. 1983. "How Women Experience Battering: The Process of Victimization." Social Problems 30 (3): 32-339.

Fleetwood, Jennifer. 2014. Drug Mules: Women in the International Cocaine Trade. London: Palgrave.

Hammersvik, Eirik. 2018. "Making Sense of 'Helping Friends': 'Flexing' Motivational Accounts of Cannabis Growing." Journal of Contemporary Ethnography 47 (1): 88-112.

Hochstetler, Andy, Heith Copes, and Michael Cherbonneau. 2017. "It's a War Out There: Contextualized Narratives of Violent Acts." Journal of Criminal Justice 53: 74-82.

Holstein, James A., and Jaber F. Gubrium. 2000. “The Self We Live By: Narrative Identity in a Postmodern World." Symbolic Interaction 23: 109-130.

Lim, Ban Hong, Christine E. Valdez and Michelle M. Lilly. 2015. "Making Meaning Out of Interpersonal Victimization: The Narratives of IPV Survivors." Violence against Women 21 (9): 1065-1086.

Lindegaard, Marie. 2018. Surviving Gangs, Violence and Racism in Cape Town: Ghetto Chameleons. London: Routledge.

Loseke, Donileen. R. 2007. “The Study of Identity as Cultural, Institutional, Organizational, and Personal Narratives: Theoretical and Empirical Integrations." Sociological Quarterly 48 (4): 661-688.

Maruna, Shadd. 2001. Making Good. Washington, DC: American Psychological Association.

McIntosh, James, and Neil McKeganey. 2000. “Addicts' Narratives of Recovery from Drug Use: Constructing A Non-Addict Identity." Social Science \& Medicine 50: 1501-1510.

Meyer, Silke. 2016. "Still Blaming the Victim of Intimate Partner Violence: Women's Narratives of Victim Desistance and Redemption when Seeking Support." Theoretical Criminology 20: 75-90.

Miller, Jody, Kristin Carbone-Lopez, and Mikh V. Gunderman. 2015. "Gendered Narratives of Self, Addiction and Recovery among Women Methamphetamine Users." In Narrative Criminology: Understanding Stories of Crime, ed. Lois Presser and Sveinung Sandberg, 69-95. New York: New York University Press.

Pemberton, Antony, Eva Mulder, and Pauline G. M. Aarten. 2019. "Stories of Injustice: Towards a Narrative Victimology." European Journal of Criminology 16 (4): 391-412.

Presser, Lois. 2012. "Getting on Top through Mass Murder: Narrative, Metaphor, and Violence." Crime, Media, Culture 8: 3-21.

Presser, Lois, and Sveinung Sandberg. 2015. Narrative Criminology: Understanding Stories of Crime. New York: New York University Press.

Struthers, Cynthia B. 2014. “The Past is the Present: Gender and the Status of Rural Women." In Rural America in a Globalizing World, ed. Conner Baily, Leif Jensen, and Elizabeth Ransom, 489-505. Morgantown: West Virginia University Press.

Sandberg, Sveinung. 2013. "Are Self-Narratives United or Fragmented, Strategic or Determined? Reading Breivik's Manifesto in Light of Narrative Criminology." Acta Sociologica 56: 69-83.

Scott, Marvin B., and Stanford M. Lyman. 1968. "Accounts." American Sociological Review 33: 46-62.

Tigges, Leann, and Hae Yeon Choo. 2012. "Family Matters: Gender, Work Arrangements, and the Rural Myth." In International Handbook of Rural Demography, ed. László J. Kulczár and Katherine J. Curtis, 225-238. New York: Springer.

Walklate, Sandra, JaneMaree Maher, Jude McCulloch, Kate Fitz-Gibbon, and Kara Beavis. 2019. "Victim Stories and Victim Policy: Is there a Case for a Narrative Victimology?" Crime Media Culture 15: 199-215.

Weiss, Karen G. 2011. “Neutralizing Sexual Victimization: A Typology of Victim’s Non-Reporting Accounts." Theoretical Criminology 15: 445-467.

Westphal, Maren, and George Bonnano. 2007. "Posttraumatic Growth and Resilience to Trauma: Different Sides of the Same Coin or Different Coins?" Applied Psychology 56: 417-427.

Wood, Julia T. 2001. “The Normalization of Violence in Heterosexual Romantic Relationships: Women's Narratives of Love and Violence." Journal of Social and Personal Relationships 18: 239-261. 